2）上田，中長ら：㥛厚板の多酋乫合せ溶接に打ける過渡打よび残留 沁力, 溶接学会誌, 44-6 (1975), 464-474

3）上田，金，唡谷，山北：摩板補修溶接部门力学的特性，溶接学会 論文集, 4-3 (1986), 533-539

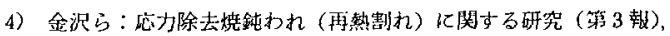
溶接学会誌, 46-8 (1977), 591-597

5）上田, 金, 山北，房：3 次元熱弾塑性問題の平面变形問題への圈 換の可能性の検討，溶接学会論文集，6-1 (1988)，32-38

\title{
溶接残留応力の生成源を用いた残留応力推定法*
}

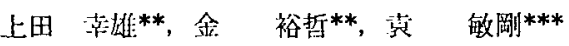 \\ A Predicting Method of Welding Residual Stress Using Source of Residual Stress* \\ by Yukio Ueda**, You Chul Kim** and Min Gang Yuan*** \\ In this paper, a predicting method of welding residual stress by using the source of residual stress \\ (inherent strain) is proposed. And the validity of the method is demonstrated by numerical experiments \\ with the aid of the finite element method. \\ Welding residual stress is produced as a result of thermal elasto-plastic behavior. Their source is \\ composed of the thermal strain and/or plastic strain, etc., which is called here inherent strain. \\ Taking a butt welding joint as an example, the sources of residual stress are estimated in different \\ sizes manufactured on the same welding condition. It is found that the distributions of the source of \\ residual stress are almost the same if the sizes of the joint are larger than that of a specific one, which is \\ named a standard size. \\ It is demonstrated that the residual stress produced in the joint of any different sizes can be predicted \\ accurately by elastic analysis using the inherent strain in a standard size of the joint, unless the sizes are \\ too small.
}

Key Words: (Welding residual stress) (Inherent strain) (Source of residual stress) (Butt welding) (Thermal stress) (FEM)

1. 緒言

溶接構造物には必然的に溶接残留応力が生じ，てれが 溶接構造物の使用性能，㭙には安全性に大きな影響を及 ぽすことが知られている，したがって，溶接構造物の強 度を精度よく推定するには溶接に上り生じる残留応力の 分布と大きさを精度よく知るととが重要となる。

溶接残留応力を簡単に予測することを目的として多く の研究がなされている1-3). 中でも, 溶接残留忘力の生 成源に注目した研究がある1.2)。しかし，溶接条件等が種 々変化した場合, 生成源をどのように決めるのか其体的 な推定方法が示されていないことから，奏用に袋されて いない。一方，部材内部をも含む 3 次元残留心力测定法 か開発され4), 残留応力の生成源を推定し, 残留応力を 求めることができることを具体的に示している5-8).

本研究では, 溶接残留応力の生成源比ついて考察す る。そして, 生成源が継手の寸法にあまり代存しないて とに注目し，一定の生成源を用いた弾性解析により，溶 接残留応力が推定できる方法を提案する。 また，乫合せ 溶接継手を例に取り，本研究で提案する残留応力推定法 の妥当性と適用性を示す。 また，溶接残留応力の生成源 の特性をも考察する.

\footnotetext{
*原稿受付 昭和62年 9 月 8 日 昭和63年度春季全国大会で論文発表

**正員大阪大学溶接工学研究所 Member, Welding Research Institute, Osaka University

*** 大阪大学大学院 Graduate Student of Osaka University
}

\section{2. 溶接残留応力推定法の提案}

\section{1 溶接残留応力の生成における特街}

浴接残留芯力は溶接熱エネルギーによる不均一温度分 们による熱膨张・双縮に起因して生じる塑性変形などに よって生成される。したがって, 溶接残留応力の分布と 大きさを決少主要な没配因子は次の三つである。

（1）鋼種（物理定数およご機械的性賔の温度依存性, 温度冷却過程で生じる相変態温度域等)

（2）拘束条件（継手形式，部材の諸寸法等）

（3）溶接条件 (入熱量，学熱・後熱の有無等）

上速のように，塑性ひずみを含む不適合ひずみが溶接 残留応力の生成源であり，本論文ではこの不適合ひずみ を総称して，固有ひずみ上呼ぶてとにする。

一般に，溶接残留応力の分布と大きさは，銅種，溶接 条作が同じであっても，継手の寸法により翼なる。 とて ろで，溶接の場合，残留応力の生成源（固有ひずみ）は 溶接部近傍のみに生成される上考えられる。このため， 銅種、溶接条件を一定とした場合，固有ひずみの存在領 域を取り团む領域（部材の諸寸法）がある程度以上大き くなると，固有ひずみの分布と大きさは無限大の大きさ を有する部材に生じる固有ひずみとほぼ等しくなると予 想される（部材の諸寸法が小さくなると，固有ひずみの 分布上大きさは変化する)。、いずれにせよ，拘束条件加 闹じ，すなわち，(1)同形式の継手で，(2)部材寸法がある 程度以上大きくなると，それに生成される固有ひずみの 分布と大きさは継手の寸法に無関保に銅種之溶接条件に 
より決まると推論される。

上述の推論が成立すれば，(1)無限大と同じ効果を有す る大きさの溶接継手の寸法を決め，(2)それに生成されて いる不適合ひずみ（固有ひずみ）を一度だけ推定してお くと，(3) 同形式の継手であれば, 寸法が種々変化して あ, 前述の固有ひずみを無応力状態の個々の継手に与え て弾性解析を行うことから，個々の継手のあらゆる点に 生している溶接残留応力の分布と大きさか，熱弹塑性解 析を行うことなしに，比較的簡単に予测できることにな る。

これが，本研究で提案する溶接残留応力推定法であ り，3節でその妥当性を検証する。

\section{2 固有ひずみの推定方法と溶接残留応力の計算法}

上述したように，本推定法を適用する場合，(1)任意の 人熱量に対し，無限大と同じ效果を有する大きさの継手 の寸法を決定し，(2)それに生成されている固有ひずみを 一度推定する。(3)それを無応力状熊の種々の寸法を有す る継手に与え, 弾詓解析する必要がある.

ここでは，有限要素法を適用して，(2)，(3)を求める場 合について説明し，(1)については 3 節 3.2 項で述べるて とにする。

溶接残留応力の生成源（固有ひずみ）の推定に対する 基礎理論4.9）お上で平面応力状熊の継手に生成されてい た固有ひずみの推定 ${ }^{8}$ に関してはそれぞれの文献に詳細 に述へている。ここでは，本論文で用いる平面态力状態 にある乫合せ溶接継手を例に固有ひずみの推定法（定ひ ずみ要素を用いた場合）の概要を述べるととにする。

溶接の場合, 固有ひずみ $\left\{\varepsilon^{*}\right\}=\left\{\varepsilon_{x}^{*}, \varepsilon_{y}^{*}, \varepsilon_{x}^{*}\right\}^{T}$ は溶接 部近傍の限られた領域にのみ生成されると考えられる。 しかし，てれに起因した容接残留応力 $\{\sigma\}$ (弾性ひずみ $\{\varepsilon\} ）$ は板全体に生じる。乙れらの関係は次式のように 表わされる。

$$
\begin{aligned}
& \{\varepsilon\}=\left[H^{*}\right]\left\{\varepsilon^{*}\right\} \\
& \{\sigma\}=[D]\{\varepsilon\}
\end{aligned}
$$

ここに

$$
\begin{aligned}
& {[D] \text { : 応力ーひずみマトリックス }} \\
& {\left[H^{*}\right] \text { : 弾性応答マトリックス }}
\end{aligned}
$$

例えば，上式において，溶接部近傍の限定された固有 ひずみ生成域の有限要素数を $m$ とすると，固有ひずみ 成分は 3 つあるので，全固有ひずみ成分は $3 \mathrm{~m}$ となる。 他方, 継手全域の有限要素数は $n(n>m)$ で, 生じる弾 生ひずみ・残留応力成分は $3 n$ となる。したがって，式 (1)の大きさは次のようになる。

$$
\begin{aligned}
& 3 n \quad 3 n \times 3 m \quad 3 m \\
& \{\varepsilon\}=\left[H^{*}\right] \quad\left\{\varepsilon^{*}\right\}
\end{aligned}
$$

上式において $3 m$ 個の固有ひずみ成分 $\left\{\varepsilon^{*}\right\}$ を決定す る場合には，式(1)を逆に解く必要がある。

そのためには，まず，\{દ\}に $3 \mathrm{~m}$ 以上の既知弾性ひず みが必要になる。実験では，弾性ひずみの計矵に種々の 方法を用いることができる。例えば，応力弛緩法ではひ ずみゲージを貼付して継手を細断し，乩緩ひずみの逆符 号として弾性ひずみ $\{\varepsilon\}$ が求まる，また，後述の数値 実験では，熱弾雉性解析で得られる弾性ひずみをそのま ま計測弾狌ひずみ $\{\varepsilon\}$ として用いる.

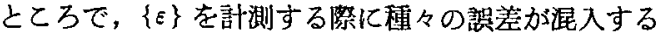
可能性がある．したがって，残差の二乗和を最小にする
条件より，次式に示す固有ひずみの最確値 $\left\{\hat{\varepsilon}^{*}\right\}$ を推定 する。すなわち，

$$
\left\{\hat{\varepsilon}^{*}\right\}=\left(\left[H^{*}\right]^{T}\left[H^{*}\right]\right)^{-1}\left[H^{*}\right]^{T}\{\varepsilon\}
$$

固有ひずみの最確值 $\left\{\hat{\varepsilon}^{*}\right\}$ が推定できると，乙れを式 (2)に代入することから，任意の位置に生じていた溶接残 留応力の最確值 $\{\hat{\sigma}\}$ が求まることになる。

$$
\{\hat{\sigma}\}=[D]\left[H^{*}\right]\left\{\hat{\varepsilon}^{*}\right\}
$$

\section{3. 溶接残留态力推定法の妥当性と適用性の 検证}

ここでは，瞬間平面熱源による薄板の突合せ溶接継手 を解析モデルとして取り上げ，有限要素法を用いた数值 実験を行い，本研究で新たに提案している残留応力推定 法の安当性を検証する.

\section{1 解析対象}

解析モデルとして，2 枚の長方形薄板を乫合女溶接す る場合を考える (Fig. 1)。

板の諸寸法は長さ $2 L$, 幅 $B$, 厚さ $h=6 \mathrm{~mm}$ とする. また，鋼材は軟釦とし，その物理定数および機械的諸性 質の温度依存性は文献(10)に示したすのを用いる。

溶接は炭酸ガス溶接を想定し，入熱量 $Q$ は䉓流 $I=$ $220(\mathrm{~A})$, 電压 $V=24(\mathrm{~V})$, 溶接速度 $v=24(\mathrm{~m} / \mathrm{h})$ およ び熱效率 $\eta=0.75$ 亡し， $Q=5 \hat{9} \dot{4}(\mathrm{~J} / \mathrm{mm})$ の㮩間平面熱 源とした。

また，解析は解析モデルの対称性を若虑し，モデルの 1/4について行った。

\section{2 基準モデルの決定}

本研究で提案する方法によって残留応力を推定する場 合，無限大と同じ效果を有する大きさの溶接継手（基準 モデルと呼ふ）に生じている固有ひずみを一度推定して おく必要がある。したがって，基準モデルの大きさを決 める必要があり，てれについて茺べる。

まず，温度履歴に注目する。

無限板の板幅 $(y)$ 方向におりる各点の最高到達温度 $T_{\max }$ をFig. 2 亿示す, $y$ が大きくなるにつれ $T_{\max }$ が 小さくなり， $y=500 \mathrm{~mm}$ 以上では $T_{\max }=15^{\circ} \mathrm{C}$ (空温) となる.よって, 板幅 $B \geq 500 \mathrm{~mm}$ の有限板では板幅境 界からの熱反射の影垫をはとんど受けないととになり， $B=500 \mathrm{~mm}$ 以上を無限板に相当する大きさの板幅と見 なすととができる。したがって，温度履歴に注目した基 準モデルの板幅 $B$ は $\mathrm{B}=500 \mathrm{~mm}$ として, 板長 $2 L$ を 次のように決めた。

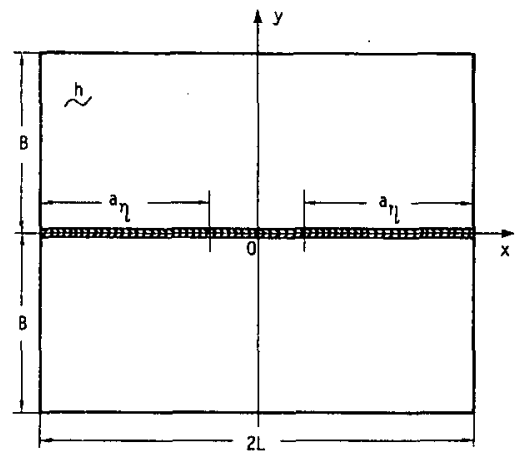

Fig. 1 Model of butt welded joint for analysis 


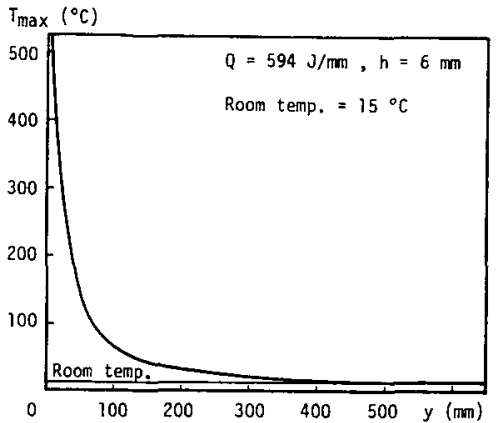

Fig. 2 Maximum temperature in the perpendicular direction to the welded line in infinite plate

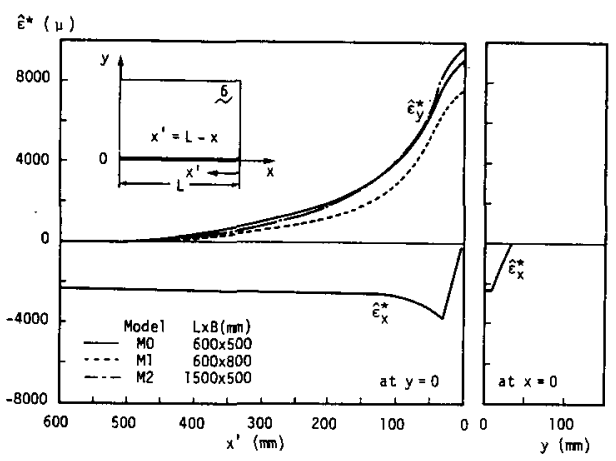

Fig. 3 Distributions of most probable values of inherent strains

板長 $2 L$ は，板端面の自由境界の影缶が板中央部にま で及ばない最小長さ $2 a_{\eta}$ 以上となるように決めた (Fig. 1). 自由境界の影響が97.5\%消失するに必要な板 端部からの距離 $a_{\eta}$ は炊式7 から計算できる。すなお ち.

$$
L>a_{\eta}=3.8 \sqrt{b(B-b)}
$$

とこに,

$b:$ 固有ひずみ生成域の半幅（この例では，後述す るように $34 \mathrm{~mm}$ であった).

式(4)より， $a_{\eta}$ を求めると， $a_{\eta}=480 \mathrm{~mm}$ であった。 し たがって, 板長 $L$ は $L=600 \mathrm{~mm}$ とした。

以上より, 板厚 $h=6 \mathrm{~mm}$ の軟鋼で, 入熱量 $Q=594$ $\mathrm{J} / \mathrm{mm}$ とした場合，基準モデル M0 の大きさは $B_{0}=$ $500, L_{0}=600(\mathrm{~mm})$ とする。なお，乙てで設定した基準 モデルの罗当性を次のように検証した。

基準モデル M 0, モデル M $1(L=600, B=800(\mathrm{~mm}))$ およびモデル M $2(L=1500, B=500(\mathrm{~mm}))$ 飞対し熱 弾整性解析を行い，弾性ひずみを求めた．乙の弾性ひず みを用いて，剪断固有ひずみ成分を無視し，固有ひずみ $\left\{\varepsilon^{*}\right\}=\left\{\varepsilon_{x}^{*}, \varepsilon_{y}^{*}, 0\right\}^{T}$ を推定した（剪断固有ひずみ成分 を無視した詳紐な理由は次項で迟べる)。をの結果を Fig. 3 に示す。とれによれば，板端部からの溶接線方向 固有ひずみ成分の最確做 $\hat{\epsilon}_{x}^{*}$ はモデルの大きさに関係な く，同じ值となっている．しかし，溶接線直角方向成分 の最確值 $\hat{\epsilon}_{y}^{*}$ は，モデルの大きさにより，大きさが多少 異なっている，その理由として， $\hat{\varepsilon}_{x}^{*}$ は溶接線近傍の溶接

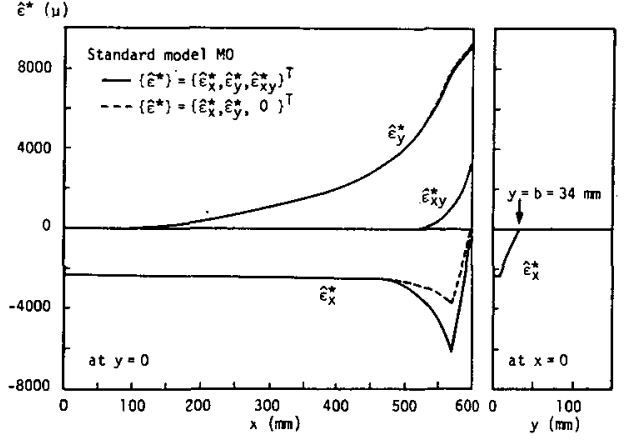

Fig. 4 (a) Distributions of most probable value of inherent strain components
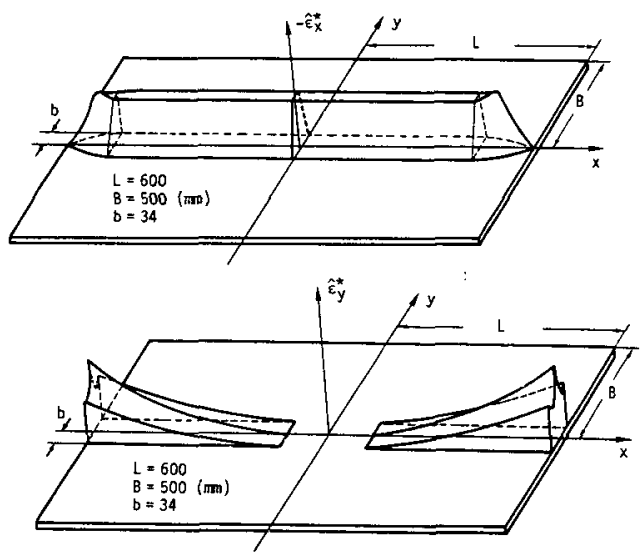

Fig. 4 (b) Schematic representations of distributions of inherent strain components in butt welded joint

線方向の収縮に対する拘束の大きさに依存して決まる が， $\hat{\varepsilon}_{y}^{*}$ は面内の㴊性，すなわち，L/B 亿大きく化存す るためと考えられる。

3.5 項で詳述するが，笑合せ溶接の埸合，溶接残留店 力の分布と大きさを決める支配固有ひずみ成分は $\hat{\epsilon}_{x}^{*} て ゙$ あり，てれは 3 モデルで同じであった，また，基準モデ ル M0 から推定した固有ひずみを用いて具現したモデ ルM1，M 2 の溶接残留応力のそれぞれの熱弹塑性解析 結果に対する不変推定值 $\hat{s}_{\sigma}$ は各ヶ $9.7,8.7 \mathrm{MPa}$ であ った．以上より，モデル M0 の大きさは基準モデルと して姩当である之考えた。

\section{3 基準固有ひずみとその精度}

基準モデル M0 に刘し熱弾塑性解析を行い，得られ た弾性ひずみを式(3)の $\{\varepsilon\}$ 亿用い，推定した不適合ひ ずみ（固有ひずみ: $\left.\left\{\hat{\varepsilon}^{*}\right\}=\left\{\hat{\varepsilon}_{x}^{*}, \hat{\varepsilon}_{y}^{*}, \hat{\varepsilon}_{x y}^{*}\right\}^{T}\right)$ の分布を Fig. 4(a) に奏線で示す.

ところで, 突合せ溶接の場合, 剪断固有ひずみ成分 $\varepsilon_{x y}^{*}$ は板端部にのみ生成されている (Fig. 4(a)). した がって， $\varepsilon_{x y}^{*}=0$ として推定した固有ひずみ存用いても， 残留応力の具現性が高ければ，未知固准ひずみ成分の個 数が $2 / 3$ となり，固有ひずみの推定に聖する手間，時間 などが诚少することになる。このような利点を利用する ため，剪断固有ひずみ成分を無視し，固有ひずみ： 
$\left\{\hat{\varepsilon}^{*}\right\}=\left\{\hat{\varepsilon}_{x}^{*}, \hat{\varepsilon}_{y}^{*}, 0\right\}^{T}$ として推定した，その結果を Fig. 4 (a)に破線で示す。乙れによれば，前断の固有ひずみ成 分 $\varepsilon_{x y}^{*}$ の役割を溶接線方占向の圆有ひずみ成分 $\hat{\varepsilon}_{x}^{*}$ 力補一 ているような分有となっている。

Fig. 4(a) から，固待ひずみは溶接線より $y=34 \mathrm{~mm}$ までの狭い領域化のみ祢在していることがわかる。また 溶接線方向成分 $\hat{\varepsilon}_{x}^{*}$ は端部を除く各横断面で间じ分猚を しており，溶接線直挣万们成分 $\hat{\varepsilon}_{y}^{*}$ は溶接線に沿って故 物線のような分布をしている (Fig. 4(a)). これらを模式 的に示したのが Fig. 4(b) である。

本論文では， $\hat{\varepsilon}_{x y}^{*}=0$ として基準モデルから推定した 固有ひずみ： $\left\{\hat{\varepsilon}^{*}\right\}=\left\{\hat{\varepsilon}_{x}^{*}, \hat{\varepsilon}_{y}^{*}, 0\right\}^{T}$ を基準固有ひずみと 呼び，てれを基本として，以下の議論を進めることにす る。

なお，基準固有ひずみを用いても残留応力の具現﨡が 高い。乙れを次に示しておく。

基準モデル M0 から推定した基準固有ひずみを無応 力状態の基準モデルに与え弹性解析を行い，固有纫力 （残留応力）を求めた．固有応力と熱弾盟性解析より求 めた残留応力とを比較したのが Fig. 5(a)，(b) である. 中 㶧断面 ( $x=0$, Fig. 5(a)) 拈よび $x=400 \mathrm{~mm}$ (板の端よ り $200 \mathrm{~mm}$ 内側) の横断面（Fig. 5(b)）における残留応 刀分布を兒る亡，两者はよく一致している。また，板全 体に生じていた溶接残留応力（熱弹塑性解析結果）に対 する不変推定値 $\hat{s}_{\boldsymbol{\sigma}}$ は $\hat{s}_{\boldsymbol{s}}=6.5 \mathrm{MPa}$ であった。

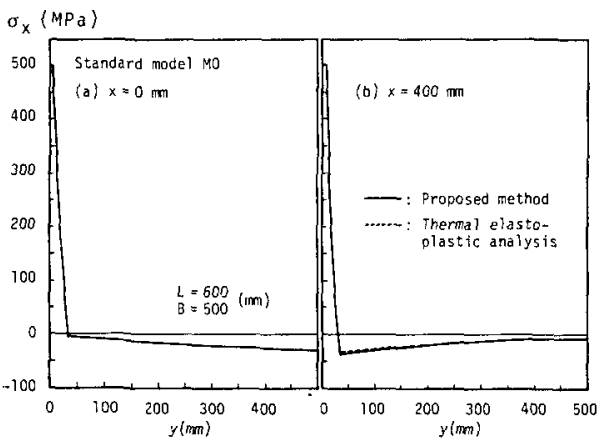

Fig. 5 Welding residual stresses obtaine by using standard inherent strains and by thermal elasto-plastic analysis
以上の上うに，哭合せ溶接の埸合，䬱断固有ひずみ成

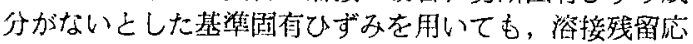
クの具現精度が高いと上を確怒した。

3.4 基準固有ひずみ分布の与え方とその妥当性の 検討

基整湖有ひずみ分优を種々の寸洼のモデルに与える坊

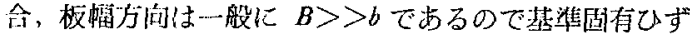
みを板幅方向に与えるのに不都合が生じないが，モデル の長さ $L$ が基準モデル M 0 の長さ $L_{0}$ と異なる場合， 基準固有ひずみをそのまま与えることがでさない，この 場合，乫合甘溶接継手（基集モデル）に生じる固有ひず み分布 (Fig. 4) の特徴, 寸なわち，板の端部を除く中 夯部分で基準固有ひずみは一定に分布していたととか ら，次のように基準固有ひずみを与えることにする。

$L>L_{0}$ の場合，板の端部を一致させ，端部加ら $L_{0}$ ま

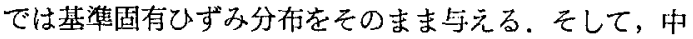
块加ら $L-L_{0}$ までは基準固有ひずみの中央断面における 行布をそのまま延長 $\left(\hat{\varepsilon}_{x}^{*}:\right.$ 一定，鋉=0)して用いる。 た， $L<L_{0}$ の場合も板端部を一致させ，板長 $L$ まで， 基準モデルの固有ひずみ分布をそのまま用いる。

基準固有ひずみを上述の方法で寸法か種々異なるモデ ル M 3 M 6 に与え, 弾性解析を行い, 求めた中央断面

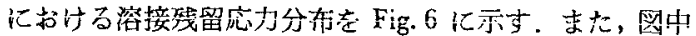
に熱弹塑性解析による結果屯示している。

結果によれげ，寸法の異なるいずれの場合でも，溶接 残留応力の分布形状と大きさがよく具現できているが， 板幅 $B \leq 100 \mathrm{~mm}$ では，基準固有ひずみをそのまま適用 すると溶接残留忍力の推定精度が低下するよううである。

\section{5 固有ひずみ成分と残留応力の具現精度}

まず，固有ひずみ成分が残留応力の分布形状に与える 影幚を考察する。

固有ひずみ成分の中で，锅接線方间成分 $\hat{\varepsilon}_{x}^{*}$ 亡溶接 線㨁角方向成分 $\hat{\varepsilon}_{y}^{*}$ とを別々に基準モデル M 0 に与え 弾性解析を行い求めた応力分布を Fig. 7 に示す。乙れに 上れば，溶接牫留応力の分布之大きさを決める支配固有

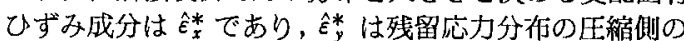
傾きに大きく影謷を及ばすことがわかる。

ところで, 前項で示したが, 板寸法が基準モデルより 小さい領域に対しても，基準固有ひずみを用いて具現さ 机る溶接残留応力の精度が高加た。てては，残留応力

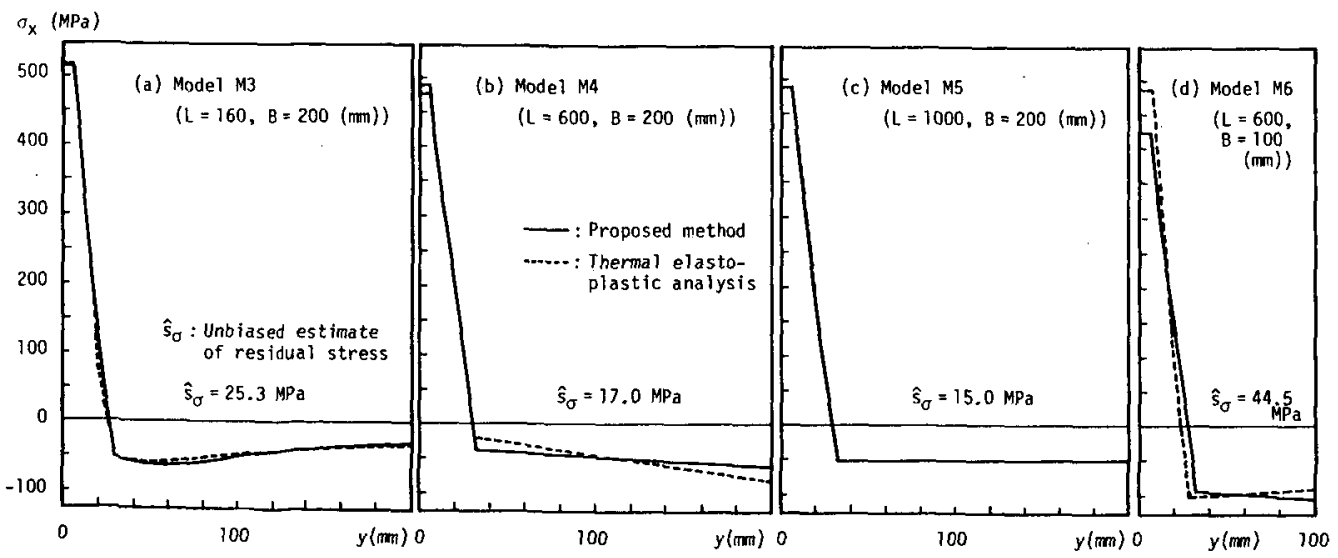

Fig. 6 Reproducibility of welding residual stresses using standard inherent strain 


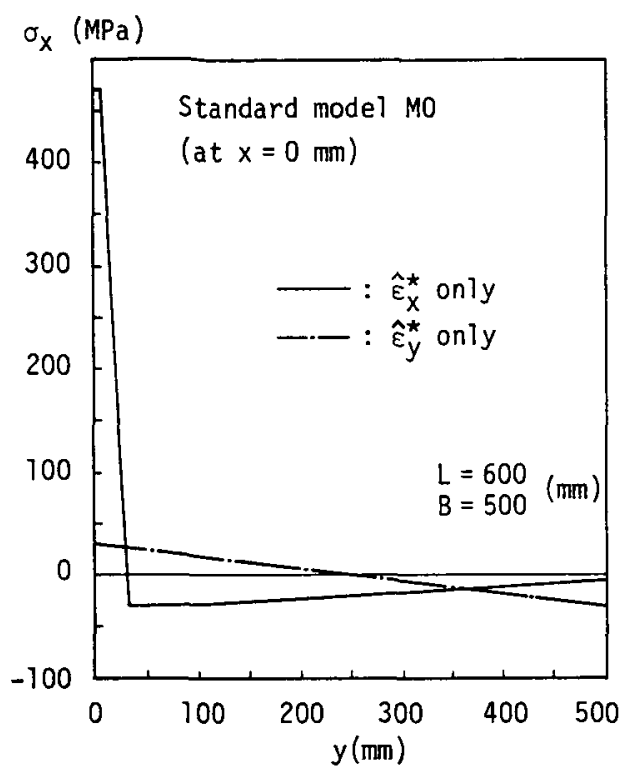

Fig. 7 Stresses produced by $\hat{\varepsilon}_{x}^{*}$ and $\hat{\varepsilon}_{y}^{*}$ respectively

の分布と大きさを決める支配固有ひずみ成分が溶接線方 问成分 $\hat{\epsilon}_{x}^{*}$ であったためである，すなわち，支配固有ひ ずみ成分である $\hat{\varepsilon}_{x}^{*}$ の生成は溶接線近傍の溶接線方向の 収縮化対する拘束の大きさに依存する。したがって，板 寸法が基準モデルに比べ多少小さくなっても，溶接線方

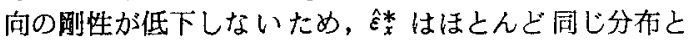
大きさになるためと考えられる。

一方，同じ基準固有ひずみを寸法の異なる継手に与え るにあかかわらず，長さ方向の各横断面化生じる溶接残 留応力 $\sigma_{x}$ の分布形状が変化する。すすなわ $5, x / L=0$, $0.5,0.9$ の各断面に生じる応力分布の形状を $L$ と $B$ との比：L/B で分類して模式的に示したのが Fig. 8 で ある。

$$
\begin{array}{lll}
\text { 範囲 } & \text { I } & \multicolumn{1}{c}{L / B<1} \\
\text { 範囲 } & \text { II } & 1<L / B<4 \\
\text { 範团 } & \text { III } & 4<L / B
\end{array}
$$

倜々の範团において，中央断面传じる応力分布形状 を Type A, Type B, Type C と呼ぶことにすると，籁 用1は Type A の分布が全長に及び，範囲】になると， 中央断面では Type B, 端面に近づくと Type A にな る、また，䇩囲林では，中央断面は Type C, 端面に近 づくにつれ Type B, Type A と変化する.

ここで, Type Aは, 継手の長さが幅に比べて短く， 端面 $(x=L)$ である自由境界の効果, すなわち, 荕断遅 れが支配的な影帮として現われた分布である. Тype B は剪断遅れの影響は消えているが，継手が余り長くない ので，端面近傍に存在する $\varepsilon_{y}^{*}$ による面内曲げの影製 が㩆著に現われた分布になっている. Type $\mathrm{G} は$ は，板が 十分長いため，端面の效果である剪断遅れおよび端部近 傍の $\varepsilon_{y}^{*}$ による曲げの影響が中央部にまで及ばない，

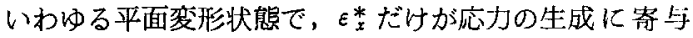
する 1 軸応力状態となっている.

本論文で提案した方法で残留応力を推定する場合，板 寸法の相違より字応力分布の形状により, 推定精度が左.

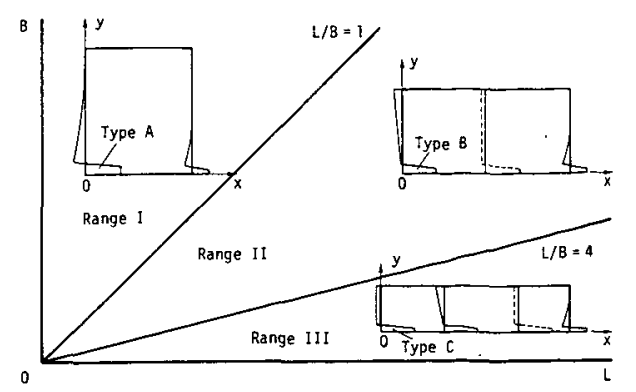

Fig. 8 Feature of welding residual stress distributions in three ranges of $\mathrm{L} / \mathrm{B}$

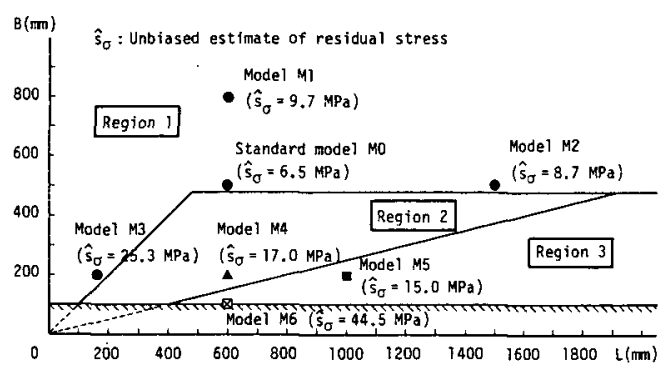

Fig. 9 Applicability of proposed method

右されるようである。すなわち，Type A と Type C の 志力分布に刘しては推定精度は高い。しかし, Type B の推定精度はやや低く，具体的には，生縮側の傾きに多 少の誤差が現われるようである。乙れは， $L / B$ (面内㴊 性）の大きさによって， $\varepsilon_{y}^{*}$ 加変化するにあかかわら ず, 基準モデルから推定した $\hat{\varepsilon}_{y}^{*}$ 係なく用いたためであると考えられる。

ここで，基準固有ひずみの分布領域を考虑して，本推 定法の適用範囲を $L=B>100 \mathrm{~mm}$ とすると，推定精度 は大体次のようになる（Fig.9）

(1) 領域 1

$L / B<1$ あるいは $B \geq 500(\mathrm{~mm})$ を满たす領域では， 全溶接長にわたって高精度である。

(2) 領域 2

$1<L / B<4$ 加 $B<500 \mathrm{~mm}$ を満たす領域では, 中 央断面の応力分布は Type B になり，やや精度が低下す る.しかし，端部では Type A となり，高精度となる。 (3) 領域 3

$4<L / B$ かつ $B<500 \mathrm{~mm}$ を満たす領域では，中央 および端部に近い断面では，それぞれ Type C および Type A の応力分布となり, 高精度である. しかし, そ の中間では Type B の分布になるのでやや精度が低下す る.

以上の結果より，前節で述べた推論のように，一度基 準モデルから固有ひずみを推定しておき，乙れを板寸法 $(L, B)$ 方種々変化する継手に与元弾性解析することか ら, 寸法の変化と共に変化する溶接残留応力の分布之大 きさが精度よく具現できるととが明らかになった。てれ により, 本研究で提案した溶接残留応力推定法の妥当性 と適用性が碓認できた。 


\section{4. 結萻}

得られた主な結果を要約すると次の通りである.

(1) 溶接残留応力の生成源，すなわち，不適合ひずみ （固有ひずみ）の特性を利用した溶接残留応力推定法を 開発し，突合甘溶接を例に取り，その妥当性之適用性を 示した。すなわち，鍓種，溶接条件を一定にした場合， 溶接継手の寸法がある程度以上大きくなり，無限板之闹 じ効果を示す有限板（基準モデル）に生じる固有ひずみ は，無限板に生成される固有ひずみとほぼ同じである。 したがって，そのような有限板に生成される固有ひずみ （基準固有ひずみ）を一度推定しておりば，部材寸法が 種々変化してもそのつど熱弾然性解析を実施する必要は なく，推定した基準固有ひずみを与え，弾性解析を行う と溶接残留応力か簡単に求まる。乙れが新た江開発した 溶接残留応力推定法の特徽であり利点である。また，そ の推定精度は高い。

(2) 突合せ溶接の場合, 俆断固有ひずみ成分 ${ }_{x y}^{*}=0$ と した基準阎有ひずみ： $\left\{\hat{\varepsilon}^{*}\right\}=\left\{\hat{\varepsilon}_{x}^{*}, \hat{\varepsilon}_{y}^{*}, 0\right\}^{\mathrm{T}}$ を用いて， 浴接残留芯力の分布之大きさが精度よく具睍でさる。

(3) 溶接残留忘力分布と大きさを決める支配固有ひ
ずみ成分は $\varepsilon_{x}^{*}$ である。 また，溶接線淔角方向成分 $\varepsilon_{y}^{*}$ は残留応力の圧縮側の攧きに大きな影製を及ばす。

\section{考 女 献}

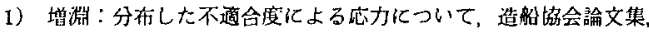
88 (1955), 189-200

2）滕本：固有ひずみの概念に上る溶接残留応力および溶接变形の解 析法, 溶接学会誌, 39-4 (1970)，236-252

3）佐藤，寺畸：構造用材料の溶接残留忍力分布に及ぼす溶接諸条件 の影䇒，溶接学会誌，45-2 (1976)，105-156

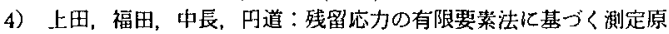
理亡推定值の信賴性，目本造船協会論文集，138 (1975)，525 -533

5）上田，福田，谷川：固有ひずみ論に基づく 3 次元残留応力測定法, 造船協会論文集, 145 (1979), 215-223

6）上田，福田，愊田：長い溶接継手の 3 次元残留応力測定理論，溶 接学会誌，49-12 (1980)，845-853

7)上田, 福田：3 次元溶接残留応力の簡易測定法阔关する研究，溶 接学会誌，52-2 (1983)，115-117

8）上田、金、梅国：浴接線儿莗直な薄板のみ用いた 3 次元残留応力 測定理論，溶接学会論文集，3-3 (1985), 611-616

9）上田，中長，金，村川：残留応力測定法の基礎理論（数值解析入 門), 溶接学会誌, 55-8 (1986), 458-465

10）上田，金，唡谷，山北：厚板㭪修溶接部の力学的特性，溶接学会 諭文集，4-3 (1986)，533-539

\title{
サーマルスリーブ付ノズルの高周波加熱応力改善法の開発*
}

\author{
坂田信二**, 榎本邦夫**，清水 翼**，佐川 涉*** \\ Development of the Induction Heating Stress Improvement for a \\ Nozzle with a Thermal Sleeve* \\ by Shinji Sakata**, Kunio Enomoto**, Tasuku Shimizu** and Wataru Sagawa*** \\ The Induction Heating Stress Improvement (IHSI) technique is regarded as one of the most effec- \\ tive remedies for intergranular stress corrosion cracking (IGSCC) cocuring in the heat affected zone (HAZ) \\ of susceptible stainless steel in some boiling water reactor piping systems. In this process, cooling water \\ must flow at a velocity high enough to keep the inside surface of the pipe relatively cool, creating a high \\ temperature gradient through the pipe wall. However, nuclear plant pipings, where forced flowing \\ during this process may be difficuit, have been welded. This paper presents computer simulation analyses \\ and experimental verifications of post-IHSI residual stress distribution of the welded portion of a nozzle \\ with a thermal sleeve, where forced water cooling is difficult. From these analyses and experiments a \\ new IHSI technique is developed. This technique consists of new heating method which has tempera- \\ ture grandient through both the pipe wall and longitudinal direction.
}

Key Words: Induction heating stress improvement (IHSI), Intergranular stress corrosion cracking (IGSCC), Heat affected zone (HAZ), Nozzle with a thermal sleeve, Stress corrosion cracking (SCC), Welding residual stress, Short period heating with axial temperature gradient method (SPAT)

1. 緒

\section{䨐}

米国の沸騰水型原子炉（Boiling Water Reactor 以下，

*原稿受付 昭和 62 年 4 月 7 日 昭和63年度春季全国大会で論文発表

**正員 (株)日立作所機械研究所 Member, Mechanical Engineering Research Laboratory, Hitachi, Ltd.

***正員 (株)日立整作所日立工場 Member Hitachi Works. Hitachi, Ltd.
BWR と呼ふ心) においてオーステナイト系ステンレス銅 配管の溶接熱影娊部 (Heat Affected Zone 以下, HAZ 之呼ぶ）に度力腐食割れ（Stress Corrosion Cracking 以 下，SCC と呼ぶ）による微小き裂が発見されて以来， SCC の発生メカ二ズムの解明とその対策法の開発が精 力的に進められて来た。

$\mathrm{SCC}$ は，塎接残留応力や運転時応力の応力因子と溶 接熱による材料の鋭的化や合金元素の含有量などの材料 